\title{
УКPAÏHCbKA ЛITEPATУPA
}

УДК 821.161.1-141.1

DOI https://doi.org/10.32838/2663-6069/2020.4-4/01

Богатирьова К. В.

Київський національний торговельно-економічний університет

Розум А. П.

Київський національний торговельно-економічний університет

\section{ПРЕРОМАНТИЧНІ МОТИВИ В «ОДЕ В ПОХВАЛУ ЛЮБВИ» ВАСИЛЯ РУБАНА}

Естетика класицизму чітко визначила ієрархію жанрів і регламентацію творів, адже адресатами були не абстрактні особи, а реальні шановані громадяни у суспільстві, історичні постаті, меценати, світські та цеерковні діячі. Украӥнський поет, літописець, перекладач, видавеиь Василь Григорович Рубан (1742-1795) надрукував «Оду в похвалу любви» у своєму журналі «Старина и новизна» у 1773 роиі. Він був новатором в украӥнській літературі, тому щзо майстерно використав тему кохання й одичну форму. Ця ода возвеличувала внутрішній світ людини і його значущість, чуттєву сторону ї̈ буття, щуо не було характерним для жанру оди кінцяя XVIII cm. і першої третини XIX cm. Основна мета автора полягала не у захопленні певними подіями, справами, подвигами чи вчинками конкретного адресата, а в наповненні твору преромантичними мотивами, щьоб передати читачам таємну силу кохання. Молодий поет не прославляв розум із раціональним відношенням до життя, а возвеличив сердечні переживання та любов, адже сенс життя, на думку автора, не тільки в служінні суспільству, а й у простій земній радості захоплюватися коханою людиною. Василь Рубан зберіг одичну форму (дециму) і протиставив раціональність чуттєвості у власній поетичнохудожній інтерпретації. Він не звертався до розуму людини, поет возвеличив кохання як найкраще почуття. Автор використав урочистий стиль і тон, образи та сюжети із античної міфологї та історії і продовжив літературні традиції Еразма Роттердамського, Олів'є де Маньї, Андре Шеньє. Античні образи, стилістичні фігури, як компоненти високого стилю, використані В. Рубаном для надання урочистості та емоційної експресивності, щуоб показати захоплення поетом особистої сфери індивіда. Проаналізовано основні тропи поетичного мовлення (епітет, персоніфікація, літота, антитеза, гіпербола).

Ключові слова: жанр, ода, любов, преромантизм, античність, почуття, мотив.

Постановка проблеми. Ода належала до «високого жанру» станової літератури, їі творцями були церковні (семінаристи і священики) й світські (студенти, викладачі, професори, службовці) автори, котрі задовольняли смаки й уподобання монархів, спадкових аристократів, орієнтувались на трактати Аристотеля, Н. Буало, М. А. Віди, А. Мінтурно, Ю. Ц. Скалігера, М. Сарбєвського, М. Довгалевського, Ф. Прокоповича. Українські одописці чітко усвідомлювали свою важливу роль в історико-літературному процесі, адже вони зосереджували увагу на реальних історичних постатях і подіях, прагнули донести до нащадків інформацію про конкретні справи й вчинки шано- ваних адресатів. Жанр оди, котрий був провідним у добу класицизму в європейських літературах, у процесі свого тривалого історичного розвитку постійно змінювався, набував нових тематичних векторів, змінювалися система віршування, стиль, адресат, коло реципієнтів. Треба зазначити, що український класицизм розвивався під впливом європейських літератур, хоча мав і власні традиції в давньому письменстві. Так, поети-гуманісти кінця XVI-XVII століть прославляли достойників iз шляхетського стану, присвячували твори містам як центрам розумних справ, зосереджували увагу читачів на людських чеснотах та гідних вчинках адресатів. Ментальний поступ був найвищим 
щаблем людського розвитку й громадсько-державні інтереси ставилися вище за особисті й були першочерговими для класицистів. Літературознавець I. Лімборський слушно зауважив, що українська література XVIII століття «була зорієнтована на пріоритетність інтелектуальних цінностей, тих цінностей, що були загалом характерні для програмних настанов класицизму, в тому числі й просвітницького» [7, с. 49].

Ода як «високий» жанр відображала важливі соціально-політичні події в країні. Оди зазвичай писали на пошану світських та церковних осіб, однак у кінці XVIII ст. під впливом преромантичних віянь цей жанр поступово втрачає своїх традиційних адресатів і починається процес деканонізації жанру, який полягав у поступовому відході від нормативності й строгої регламентації, притаманних класицистичним канонам. Українсько-польський дослідник С. Козак вказує, що «XVIII ст. <..> не виключно вік «розуму», що народжує опозицію, яка характеризується наступом «почуття» [4, с. 16]. Ідейно-стильові тенденції преромантизму, які «спростовували притаманні класицизму та просвітництву культ розуму <...> наголошували на важливості уваги до сердечних переживань та їх передбачуваних спалахів, обстоювали критерії шляхетного естетичного смаку й оригінальності» $[8$, с. 267].

Варто зауважити, що тема кохання була досить популярною у світовій літературі. Відомі вірші давньогрецької поетеси Сапфо, автора «Любовної оди» Еразма Роттердамського, Олів’є де Маньї члена організованого П'єром де Ронсаром літературного гуртка «Плеяди», який у «П'ятій книзі од» (1552) вміщує оди «У розлуці з коханою», «Анетті 3 проханням про поцілунок», які прославляли кохання до жінки. Андре Шеньє написав оду «Фанні» (1790), присвячену Фанні ле Култьо, якою поет захоплювався і висловив у творі свої щирі любовні почуття.

Аналіз останніх досліджень і публікацій. Літературна, історична й журналістська спадщина києво-могилянця Василя Григоровича Рубана (1742-1795) не була об'єктом спеціального вивчення і тому ще недостатньо досліджена в українському літературному процесі. Розвідки Б. Модзалевського, Л. Гінзбург, 3. Хижняк та авторки цієї статті, котрі займалися вивченням цієї проблеми у різні періоди, частково розкривають постать В.Г. Рубана та його літературноісторичну творчість. Олександр Авербух, український поет, перекладач і літературознавець, який зараз працює в Торонтському університеті, напи- сав статтю «Неизвестные стихотворения Василия Рубана» (2017), дослідив та оприлюднив неопубліковані раніше «побутові» вірші, які були написані в останній рік життя поета (1794-1795).

Постановка завдання. Мета пропонованої статті - проаналізувати «Оду в похвалу любви» (1773) Василя Григоровича Рубана, випускника Києво-Могилянської академії, літописця, перекладача, видавця, журналіста і поета, присвячену темі кохання і написану під впливом засад преромантичної естетики.

Виклад основного матеріалу. Варто наголосити, що діяльність В. Рубана тісно пов'язана 3 літописанням. 3. Хижняк вказує, що Рубан перший опублікував розвідку про академію «О Киевских училищах», підготовлену ректором Самуїлом Миславським (1773) [15, с. 36]. У 1777 році він видав «Краткую летопись Малыя России с 1506 по 1776 год, с изгнанием настоящаго образа тамошняго правлення й с приобщением списка прежде бывших гетьманов, генеральних старшин, полковников й иерархов», матеріали і додатки до якої були надані канцлером О. Безбородьком і котра стала фундаментальною працею для історії України. Цього ж року разом з Г. Калиновським В. Рубан видав працю «Описание свадебных украинских простонародных обрядов в Малоросии и в Слободской украинской губернии, также в великороссийских слободах, населенных малороссиянами, употребляемых», присвячену побуту українців. [5, с. 37]. На думку дослідника В. В. Кравченка, праці В. Рубана 3 історії «започаткували нову епоху в розвитку вітчизняної культури, пов'язану 3 зародженням новітнього народознавства, поширенням відповідних знань серед широкої читацької аудиторії» [5, с. 37], а 3. Хижняк зазначає, що у працях вихованців академії, зокрема і В. Рубана, закладено протест, обстоюється незалежність України, здобуті нею права і привілеї [15, с. 36].

Поетичний спадок Василя Рубана представлений численними одами, епітафіями, епіталамами, присвятами, елегіями, посланнями. Однак значна кількість од, написана ним, сервілістичні. Іменник сервілізм в українській мові (від лат. servius - раб) означає раболіпство, улесливість, лакейство, прислужництво. «Сервілізмом, власне, можна назвати пошану до якого пана як до фетиша по його самій істоті, а надто пошану, котра має егоїстичні цілі»,таке визначення дав цьому поняттю М. Драгоманов [3, с. 56]. У сервілістичних одах надмірно прославляється адресат, бо автор, зосібна, дбає про меркантильні інтереси (прохання про матеріальну 
підтримку, послугу, сприяння у вирішенні особистого питання), присвячуючи оди можновладцям. Скромне життя й невисоке становище у суспільстві постійно змушувало В. Рубана звертатися за допомогою до впливових і багатих покровителів. О. Авербух також підкреслював цю думку і вказував, що «за вірші йому (Рубану) платили обідами, провізією, предметами домашнього вжитку, грошима» [1, с. 105], а дослідниця Л. Сазонова стверджувала, що сервілістична поезія «постає як важливий компонент культурно-ідеологічного життя суспільства» [11, с. 128]. Василь Григорович як плідний творець од був незаможною людиною, часто зазнавав матеріальної скрути, тому й заробляв своєю літературною працею в можновладців, і цей факт яскраво показує й розкриває перед нами станові взаємини у житті країни XVIII століття.

Як журналіст він видавав часописи «Ни то ни сё» (1769), «Трудолюбивый муравей» (1771). У журналі «Старина и новизна» (1772-1773) написав і надрукував «Оду в похвалу любви» (1773), котра не була характерною для одичного жанру 3 його чітко визначеним адресатом і регламентованою громадянсько-політичною тематикою. Має рацію дослідниця жанру оди О. Погосян, вказуючи на окреслення автором «модального кордону» оди $[10$, c. 20]. Ці кордони зафіксовані в назві кожного твору цього жанру. Про адресата (перераховувалися всі його титули і регалії), привід для написання оди (день народження, заручини, одруження, коронація), місце та часовий простір (число, місяць, рік) дізнаємося вже 3 назви твору: ці факти дають нам важливу інформацію про культуру взаємин між представниками різних станів. Наприклад, «Ода на день всерадостнейшего торжества за предприятый и благополучно совершившийся, к не описанному счастию всея России, ее императорского величества и его императорского высочества в привитии оспы подвиг, 22 ноября 1768 года: сочиненная Васильем Рубаном», «Ода на торжественный день восшествия на престол их императорского величества Екатерины II императрицы и самодержицы Всероссийской 28 июня 1795 года», «Ода на день брачного сочетания их светлостей владеющего Курляндского герцога Петра и герцогини Евдокии Борисовны, урожденной княжны Юсуповой, февраля 23 дня 1774 г.». Таким чином, оди були тим художнім жанром, котрий фіксував важливі події у державі, а творці-одописці не зверталися до особистої сфери життя індивіда. В українській літературі кінця XVIII ст. Рубан-поет виступив новатором, використавши одичну строфу дециму, щоб уважно зосередитись на темі кохання.
«Ода в похвалу любви» має досить лаконічну назву й возвеличує внутрішній світ людини і його значущість, чуттєву сторону іiі буття, що не було характерним для од кінця XVIII ст. і першої третини XIX ст., тобто основна мета автора полягає не у захопленні певними подіями, справами, подвигами чи вчинками конкретного реального шанованого адресата, а в наповненні твору інтимним почуттям, щоб передати читачам та розкрити перед ними таємну силу кохання. Поет підносить не розум із раціональним відношенням до життя, а оспівує чуттєвість серця та естетизує любов, адже сенс життя, на думку автора, не тільки в служінні суспільству, а й у простій земній радості відчувати насолоду і задоволення від захоплення коханою людиною. На думку I. Сермана, «призначення оди полягало в тому, щоб викликати певний емоційний стан» [12, с. 42]. На перший план в оді висувається не громадський обов'язок, не уславлення видатних державних і політичних діячів, релігійних та історичних осіб, міст, подвигів чи фіксація важливих суспільно-історичних подій, а поетично-піднесений захват почуттям, яке об'єднує все людство і якому підкорюються і можновладці, і прості люди. Авторське бачення людини простежується через розкриття сили чуттєвого світу, а не інтелектуального потенціалу кожної людини, а влада кохання над людьми беззаперечна і ода яскраво ілюструє цю думку.

Образ самого автора (оповідача) в оді виступає не провісником суспільної чи приватної події у творові, а він прагне висловити свої роздуми, судження, часто навіть стає порадником для того, кому призначався твір «високого» жанру. В аналізованій оді ліричним героєм виступає сам автороповідач, вживаючи особовий займенник «я»: «Тебя хочу я воспевать» (1 строфа), «Я Имн любви возгласил», «Я вижу», «Я зрю» (2 строфа), «Я зрю Ироев прежних веков» (6 строфа). Поет створив загальний персоніфікований образ любові, яка, на думку автора, «утеха смертных и отрада», «богиня всех красот» і вона володіє всесвітом. Образ музи, яка надихає і супроводжує поета, є невід'ємним атрибутом урочистого стилю оди. Рубан в оді використав класицистичний композиційний елемент звертання до Аполлона та муз (2 строфа), натхненників усіх митців поетичного слова: «Парнасски музы с Аполлоном, // Подайте мыслям столько сил, // Чтоб нежным непрерывным тоном // Я Имн любви возгласил» [9, с. 190]. Варто зазначити, що образ музи був відомим поетам ще з античної міфології. Платон збудував олтар музам у своїй Академії; їх храми були розташовані в Олімпі, 
Трезені, Корінфі. За спостереженнями Е. Р. Курціуса, музи належать до «конкретних» образних констант літературної традиції. За античними уявленнями, вони поставлені на службу не лише творчості, а й усім вищим формам духовного життя» [6, с. 256]. Власне, образ музи як небесної натхненниці був основним для одописців.

У 3 строфі автор доводить, що кохання здатне своєю божистою енергією змінити на краще кожну людину, апелювавши до постаті римського імператора Нерона (і це єдина згадка в оді на реальну історичну особу), котрий відзначався надзвичайною жорстокістю і свавіллям: «Свирепый Нерон усмирится, // Оставит храбрость Ахиллес: // При ней философ умолкает, // Скупой пред нею чив бывает, // И варвар льет потоки слез» [9, с. 190]. Тобто В. Рубан в оді зазначив, що земне кохання - це потужна енергія добра, позитиву, що здатна змінити кожного. Преромантичні засади оди виражаються на змістовному, а не на формальному рівні. Автор не апелював до громадсько-суспільних справ поважних і шанованих у державі адресатів, а вказав, що перед нестримною силою кохання розум капітулює: «Любов повсюду обитает // И всех умы берет под власть» [9, с. 191], тобто у цих рядках простежуються наявні преромантичні мотиви, в яких возвеличуються не інтелектуальні можливості індивіда, а людське почуття, «приятность жизни».

Необхідним стильовим каноном для написання твору «високого» жанру було широке використання поетики міфології, тому ода насичена численними міфологічними образами й сюжетами $з$ античної літератури. Часто поети-одописці зображували образи богів Аполлона, Зевса, Меркурія, Морфея, Нептуна, Флори, що відповідало вимогам й настановам класицистичної естетики, увиразнювало авторську вишуканість у створенні піднесено-урочистого стилю, свідчило про досконале знання античної спадщини й орієнтацію на найкращі європейські літературно-мистецькі здобутки в письменстві. Автор чудово знав античну міфологію, яку добре опанував під час навчання в Києво-Могилянській академії, тому в оді фігурують образи богів Юпітера, Плутона, Аполлона, Нептуна, Геркулеса, які не змогли протистояти владі любові й закохувалися в богинь, німф і в смертних жінок. Для ілюстрації влади кохання і для створення позитивної атмосфери впливу на читача автор мовить про кохання «бога і смертної» і у 4 строфі використовує грецький міф про Юпітера, зачарованого неземною вродою Алкмени (дружини тірінфського царя Амфітріона), яка «в нем кровь зажгла». Щоб добитися взаєм- ності від красуні, бог перетворився на іiі чоловіка - «бренны виды принимая», бо до неї «его любовь вела». Далі у 7 строфі оповідає про Геркулеса, сина Юпітера та Алкмени, котрий став коханим лідійської володарки Омфали. Поет вмотивовано використав синоніми «храбрость, мужество, иройство», зосереджуючи увагу реципієнтів на подвигах Геркулеса, завдяки яким він прославився, проте «его необычайна сила, // Всех в страх и трепет приводила // Пока любови он не знал» [9, с. 191], тобто читач простежує зв'язок, що Геркулес, народжений від кохання бога та смертної, теж зазнав любовних чар і не міг протистояти силі кохання. У 5 строфі образний діапазон знову представлений двома міфами: 1) про бога Плутона, зачарованого Прозерпіною; 2) про Аполлона, першим коханням якого була німфа Дафна.

В. Рубан малює сенсуалістичний, гармонійний і позитивний світ добра і світла, котре випромінює людська любов. Автор в оді створює піднесеноурочисту атмосферу, аби розповісти читачам про своє захоплення найкращим почуттям - коханням, яке надихає, окриляє, змінює людину. Для досягнення творчої мети автор вживає різні античні міфи, проєктує минуле в сучасне, щоб увиразнити вічність почуття, якому непідвладні історія й час.

Урочистість і патетичність були основними стильовими ознаками оди, які відповідали класицистичним засадам і досягалися вживанням тропів (епітетів, метафор, порівнянь) та фігур (анафор, апокриз, алітерацій, риторичних окликів). «Ода в похвалу любви» Василя Рубана написана децимою і композиційно складається 38 строф. У ній основними тропами поетичного мовлення $\epsilon$ епітети, котрі надають підвищену експресивність й емоційну виразність творові та створюють відповідний урочистий стиль й піднесений настрій для реципієнтів: а) епітети, що відображають зорові та чуттєві сприйняття, витримані в дусі класицизму: «позлащенные чертоги», «век златой», «дивны чудеса»; б) Рубан широко використовує антитезу, характерну для урочистого ораторського стилю: «И в жарком, и в холодном круге /Ея зрим дивны чудеса!», «Любовь в нем лютость утолила, Из тигра агнцом претворила», «Падут с землею небеса», «На верх Олимпа поднимались / И в преисподню низвергались»; в) щоб показати всесвітню силу кохання, автор використав слова, що позначають сторони світу: «Везде ей жертвы воздают: // На Весте, Осте, Норде, Юге» [9, с. 192]; а також тропи: г) алітерації «Плутон плененный Прозерпиной», вжитій у 5 строфі; д) літоти «Для коих свет казался мал»; е) персоніфікації «Уже 
мой дух в восторг приходит»; є) гіперболи «И варвар льет потоки слез». У зазначеній оді риторичні фігури оклику вжиті в першій та восьмій (останній) строфі. Думки поета сконцентровані на роздумах про найсильніше людське почуття - любов, яка возвеличується як найвища людська моральна цінність. Автор прагнув викликати певні емоції та принести естетичну насолоду слухачеві своїм твором, використавши для цього різноманітні сюжети з античної літератури та історії, що відповідало канонам та естетиці класицизму.

Висновки. Історія української літератури досить тривалий і складний процес, коли в різні часи й періоди одні письменники були дуже популярними, а їхні твори всебічно досліджува- лися багатьма науковцями, проте були й такі, про яких згадували лише кількома реченнями, а їхні здобутки в поетичній спадщині й досі залишаються «білими плямами» у вітчизняній літературі. Таким чином, і в двадцять першому столітті існує нагальна потреба грунтовно досліджувати спадок саме тих українських авторів, котрі жили, навчалися й працювали в Росії та в інших країнах. Василь Рубан, який багато зробив для розвитку національної історії, літописання, журналістики, ім'я якого несправедливо забули, а його багатогранна творчість ще потребує детального наукового вивчення для повної реконструкції як його доробку, так і історико-літературного процесу національного письменства XVIII століття.

\section{Список літератури:}

1. Авербух А. Неизвестные стихотворения Василия Рубана // Вивліоөика: Vol. 5. 2017. С. 103-142.

2. Богатирьова К. Культурно-естетичні пошуки українських просвітників другої половини XVIII століття. Сборник научных трудов SWorld. Материаль международной научно-практической конференции «Современные направления теоретических и прикладных исследований '2013». Одесса : КУПРИЕНКО, 2013. Выпуск 1. Том. 26. С. 19-25.

3. Грінченко Б., Драгоманов М. Діалоги про українську національну справу / Укладач А. Жуковський. Київ, 1994. 286 с.

4. Козак С. Преромантизм в українській літературі: Джерела, зумовлення, контексти, витоки. Варшава, 2003. $227 \mathrm{c}$.

5. Кравченко В. В. Нариси з української історіографії епохи національного Відродження (друга половина XVIII - середина XIX ст.) : монографія. Харків : Основа, 1996. 296 с.

6. Курціус Ернст Роберт. Свропейська література і латинське середньовіччя / Роберт Ернст Курціус; [пер. 3 нім. А. Онишко]. Львів : Літопис, 2007. 752 с.

7. Лімборський I. Європейське та українське Просвітництво: незавершений проект? Реінтерпретація канону і спроба компаративного аналізу літературних парадигм. Черкаси : ЧДТУ, 2006. 363 с.

8. Літературознавча енциклопедія: у 2 т. / автор-укладач Ю. Ковалів. Київ : Видавничий центр «Академія», 2007. Т. 2. 624 с.

9. Рубан В. Ода въ похвалу любви // Старина и новизна, состоящая из сочинений и переводов прозаических и стихотворных, издаваемых почастно [В. Рубаном] въ Санктпетербурге, часть II. 1773. Відділ стародруків та рідкісних видань НБУ імені В. І. Вернадського, шифр Гр 5231. С. 190-192.

10. Погосян Е. Восторг русской оды и решение темы поэта в русском панегирике 1730-1762 г. г. Тарту: Тартусский ун-т, отделение рус. и славян. филологии, 1997. 158 с.

11. Сазонова Л. И. Поэзия русского барокко: (вторая пол. XVII - нач. XVIII в.). Москва : Наука, 1991. 264 с.

12. Серман И. 3. Русский классицизм. Поэзия. Драма. Сатира. Ленинград : «Наука», 1973. 284 с.

13. Словник античної міфології / укладач І. Я. Козовик, О. Д. Пономарів. Київ : Наукова думка, 1989. 240 с.

14. Хижняк 3. І., Маньківський В. Н. Історія Києво-Могилянської академії в іменах. Київ : Видавничий дім «КМА», 2003. 184 с.: іл.

15. Хижняк 3. I. 3 історії Києво-Могилянської академії XVII-XVIII ст. Київ : Видавничий дім «Києво-Могилянська академія», 2005. 64 с.

\section{Bogatyrova K. V., Rozum A. P. PRE-ROMANTIC MOTIFS IN VASYL RUBAN'S "ODE IN PRAISE OF LOVE"}

The article is devoted to Ukrainian poet, chronicler, translator, and publisher Vasyl Hryhorovych Ruban (1742-1795) and his literary heritage. The poet was the innovator in Ukrainian literature, because he skillfully used the theme of love and ode form and imbued the ode with pre-Romantic content. The aesthetics of classicism clearly defined the hierarchy of genres and regulation of works, because the addressees were not abstract figures, but real respected citizens in the society, historical figures, philanthropists, secular figures and church leaders. Vasyl Ruban published "Ode in praise of love» in his magazine "Starina i novizna" in 1773. This ode glorified the inner world of a man and its significance, the sensual side of his existence, which was not characteristic 
of the end of the XVIIIth century and the first third of the XIXth century. The author's main purpose was not to admire certain events, deeds, feats or actions of a particular real respected addressee, but this work was filled with intimate feelings to convey the readers that love had secret power. The young poet did not elevate the mind with a rational attitude to life, but glorified the sensuality of heart and love, because the meaning of life, according to the author, was not only in serving society but also in simple joy to admire a loved one.

Vasyl Ruban preserved the ode form (decima) and contrasted rationality to sensuality in his own poetic and artistic interpretation. He did not to appeal to human mind, the poet praised love as the best feeling. The author used the solemn style and tone, the images and plots from ancient mythology and history, and continued the literary traditions of European poets. The ancient images, figures of speech, as components of high style, were used by V. Ruban to give solemnity and emotional expressiveness, to show the poet's admiration of private sphere of the individual. The main tropes of poetic speech (epithet, personification, litotes, antithesis, hyperbole) have been analyzed.

Key words: genre, ode, love, Pre-Romanticism, antiquity, feeling, motif. 